\title{
The function of autophagy as a fundamental process of preserving cell homeostasis
}

\author{
Nikolina Elez-Burnjaković1, \\ Lejla Pojskić2, \\ Sanin Haverić2 \\ Ajla Smajlović ${ }^{2}$ \\ 'University of East Sarajevo, Faculty \\ of Medicine Foca, Department \\ of Preclinical Subjects, Foca, The \\ Republic of Srpska, Bosnia and \\ Herzegovina \\ 2University of Sarajevo, Institute \\ for Genetic Engineering and \\ Biotechnology, Sarajevo, Bosnia \\ and Herzegovina
}

Primljen - Received: 20/11/2020

Prihvaćen - Accepted: 01/03/2021

\section{Corresponding author: \\ Nikolina Elez-Burnjaković, PhD \\ Studentska 5, 73300 Foca \\ nikolinaa85@hotmail.com}

Copyright: @2021 Nikolina Elez-Burnjaković et all. This is an Open Access article distributed under the terms of the Creative Commons Attribution 4.0 International (CC BY 4.0) license.

\begin{abstract}
Summary
Autophagy is a dynamic process, conserved in all eukaryotes. It is responsible for the degradation of cytoplasmic content. Autophagy is crucial in cell survival and cell death. It plays a significant role in the cell response to stress, nutrient deficiencies, embryonic development, tumor suppression, response to pathogens and aging. The process of autophagy is also involved in the pathology of human diseases, such as cancer, diabetes, cardiomyopathy, and neurodegenerative diseases such as Alzheimer's and Parkinson's disease. Autophagy is a mechanism that involves degradation of cells, proteins, damaged organelles and pathogens through the lysosomal mechanisms, thus autophagy supports cell survival during starvation, hypoxia and metabolic stress. However, if extensive and/or excessive, autophagy can promote apoptosis (type I) or function as an alternative celldeath pathway, called autophagic cell death (type II). Autophagy can either promote cancer cell death, or serve as a survival mechanism against apoptosis or necrosis induced by various anticancer treatments. Given the contradictory role of autophagy during tumor initiation and progression, the use of autophagy in therapy depends on the context and must be approached individually.
\end{abstract}

Key words: autophagy, cell survival, cell death, tumor

\section{Introduction}

Autophagy (Greek meaning 'self-eating') is a dynamic process, conserved in all eukaryotes. It is responsible for the degradation of cytoplasmic content. It plays a significant role in the cell response to stress, nutrient deficiencies, embryonic development, tumor suppression, response to pathogens and aging. The process of autophagy is also involved in the pathology of human diseases, such as cancer, diabetes, cardiomyopathy, and neurodegenerative diseases such as Alzheimer's and Parkinson's disease. 
There are three types of autophagy: chaperone-mediated autophagy, microautophagy, and macroautophagy. Chaperone-mediated autophagy is present in higher eukaryotes, where chaperones bind to a specific protein leading to its unwinding and allowing it to pass through the lysosome membrane [1]. In microautophagy, the cytoplasmic content reaches the lysosome or vacuole (in plants) by invagination. However, autophagy mainly refers to the third type, macroautophagy (hereinafter autophagy), which is also the best studied [2].

The morphological characteristic of autophagy is de novo formation of autophagosomes, vesicles with a double membrane containing cytosol and captured organelles. The outer membrane fuses with the lysosome or vacuole by releasing the vesicle with the inner membrane into the lumen where the entire contents are degraded [3].

The autophagy has gained a lot of interests since 3rd October 2016, when Yoshinori Ohsumi was awarded the Nobel Prize in Physiology or Medicine for discoveries of mechanisms of autophagy. Approval of its beneficial effects in various diseases led to the wide autophagy fasting promotion. However, contradictory data about the role of the autophagy in cancer initiation and progression emphasizes the importance of individual and more careful approach in autophagy applications. The best evidence for the importance and popularity of autophagy research are publications. Since then, number of publication investigating autophagy rapidly increase (2016 - 5482; 2017 - 6509; 2018 - 7198; 2019 $8154 ; 2020$ - 9158). Only, from the beginning of 2021, 965 publications were published [4].

\section{Autophagy function}

\section{Cell survival}

During starvation, in lack of nutrients, which lasts for hours, autophagy produces the necessary amino acids, which are further used in several different ways. Within the first day of starvation, glucose is produced in the liver by gluconeogenesis, via lactate and amino acids. Alanine is delivered to the liver from peripheral tissues, primarily muscles, and is converted to glucose via the glucose-alanine cycle. Amino acids can further be used as an energy source in the Krebs cycle. In the third way, amino acids are used for intensive synthesis of proteins necessary for the adaptation of cells to starvation conditions. The greatest mobilization of nutrients through autophagy occurs during remodulating development, as the body's response to conditions (spore production in yeast, multicellular association in Dictyostelium discoideum, insect metamorphosis). It should be emphasized that the production of amino acids by autophagy is an acute or urgent response, and can support cell survival for a short time. Little is known about the role of autophagy in chronic starvation.

One of the most important roles of autophagy is the removal of cytoplasmic contents. Accumulation of abnormal proteins and deformed organelles in hepatocytes, karyomiocytes, and neurons lacking autophagy can lead to neurodegeneration or tumorgenesis. Accumulation of autophagosomes has been observed in Alzheimer's disease, polyglutamine recurrent disease (Huntington's disease, fragile $\mathrm{X}$ chromosome mental retardation, bulbar muscular atrophy, myotonic dystrophy type 1) and Parkinson's disease.

Autophagy can also serve as a transport system from the cytoplasm to lysosomes/endosomes or vacuoles. The best example is the Cvt pathway in yeast. Autophagy is also used to present endogenous class II major histocompatibility complex (MHC) antigens, which are recognized by CD $4+\mathrm{T}$ cells. Autophagy is involved in the removal of pathogens (xenophagy). Influenza antigen binds to LC3 and is incorporated into autophagosome and is represented by MHC class II molecules. Dendritic cells, on the other hand, use the autophagy pathway to recognize viral single-stranded 
RNA. Some of the toll-like receptors, the basic molecules of innate immunity, are located on plasma membranes, others on endosomes such as TLR7, which recognizes viral single-stranded RNAs and triggers an immune response, or secretion of inflammatory cytokines transported by autophagy.

Packaging of cell contents into autogaphosomes, but without degradation, is an important function of autophagy in cell survival. Autophagy can be caused by several events, including stress ER. Autophagy is thought to protect the cell by packaging ER in autophagosome. When yeast cells are treated with DTT or tunicamycin, autophagosomes with parts of the ER appear in the cytoplasm and still do not fuse with the vacuole. In this way, the dissemination of toxins in the cell is prevented. Although autophagy is involved in the immune system, it has been observed that some pathogens (Legionella pneumophila, Coxiella burneti, Brucella abortus and Porphyromonas gingivalis) use autophagosomes to protect against degradation, forming intracellular niches for survival and replication. The exact mechanism of this process is unknown. A similar example was observed in mouse hepatitis virus and picornavirus replication in vacuoles of the origin of autophagosome [5].

\section{Autophagic cell death}

Based on morphological criteria, there are three types of cell death, type I (apoptosis), type II (autophagy) and type III (necrosis) [6]. Autophagic cell death refers to a form of cell death that is morphologically different from apoptosis and is the result of excessive autophagy, respectively the presence of autophagosomes in a dying cell [7]. It is commonly described during embryogenesis, in order to maintain homeostasis, in diseased tissues, and in cell lines treated with chemotherapeutics or other cytostatics. In apoptosis (type I cell death), the cytoskeleton collapses in early stages, and the organelles remain preserved until late stages of apoptosis. In autophagy (type II cell death), there is degradation of organelles in early stages, but preservation of the cytoskeleton until later stages. Cell death by apoptosis is regulated by cascade reactions of caspases and DNA fragmentation, while in autophagy these processes occur late or not at all. Unlike necrosis, there is no inflammatory response [8].

However, an increased number of autophagy markers, such as the number of autophagosomes, does not necessarily mean an increased autophagic flux, but may be the result of blocking the maturation of the autophagosome (lysosome fusion), and if autophagic flux in a dying cell is indeed increased, it may be an attempt to save cells from death. Therefore, the true significance of autophagic cell death would be cell death by autophagy, not cell death in parallel with autophagy [9].

Shen and Codogno (2011) [10] proposed a new definition of autophagic cell death, according to which autophagic cell death is a form of necrosis in which autophagy serves as a mechanism of cell death and must meet the following criteria:

- Cell death without apoptosis mechanisms, such as caspase activation;

- Increased autophagic flux is not just the autophagy marker;

- Suppression of autophagy by pharmacological inhibitors and genetic blocking eliminates cell death [9].

- On the other hand, autophagy can serve as a mechanism of cell death by promoting apoptosis, respectively autophagic cell death due to excessive cell degradation.

\section{Autophagy and apoptosis}

Autophagy and apoptosis occur when cells are under stress. Under certain circumstances, these are two independent processes, but in others, the activation of autophagy inhibits 
apoptosis or autophagy occurs before apoptosis. Regulators of apoptosis, members of the Bcl-2 family, caspase 8, and FADD can regulate autophagy, and proteins involved in autophagy such as Atg5, beclin 1, and Atg4D play a role in apoptosis, suggesting the overlapping of these two processes. Normally, autophagy precedes apoptosis and maintain cell homeostasis, but is often described as a type II cell death known as autophagic cell death, thus acting as a guardian or executor of apoptosis depending on the environment.

The best example of the molecular overlap between the regulation of apoptosis and autophagy is the interaction of the autophagy protein beclin 1 and the anti-apoptotic protein Bcl-2. Binding of these two proteins inhibits both processes at the basal level. Under normal conditions, Bcl-2 inhibits beclin 1, and during stress they separate and further stimulate autophagy [10]. Nutrient deficiency activates JNK 1 (C-Jun $\mathrm{N}$-terminal protein kinase 1) which phosphorylates the Bcl-2 regulatory loop and then terminates the interaction with beclin 1 . Released beclin 1 triggers autophagy. Phosphorylated Bcl-2 interacts with Bax maintaining the integrity of the mitochondrial membrane preventing apoptosis. However, prolonged starvation causes JNK1-mediated Bcl-2 hyper-phosphorylation, leading to Bax dissociation and caspase-3-mediated apoptosis activation [11].

As in apoptosis, caspases are involved in the regulation of autophagy $[12,13]$. Caspases cleave beclin 1, Atg5 and p62 which inhibit autophagy. Caspase 8 inhibits autophagy by cleaving Atg3. In the absence of caspase 8 cleavage, excessive autophagy occurs in $\mathrm{T}$ cells [14]. Caspase 9, involved in the intrinsic apoptosis pathway, induces autophagy by increasing LC3 lipidation through interaction with Atg7 [12,15]. Caspase 3 cleaves beclin 1 to form two fragments of 37 and $35 \mathrm{kDa}$ with $\mathrm{C}$-terminus and N-terminus. Beclin 1 with $\mathrm{N}$-terminus is localized on the nucleus, and beclin 1 with $\mathrm{C}$-terminus on the mitochon- dria, leading to the release of cytochrome c and apoptosis [16].

\section{The role of autophagy in tumors}

In normal cells and tissues, autophagy plays a complex role. Lack of autophagy is thought to contribute to many diseases, including neurodegenerative diseases and aging. Previous work has shown that it suppresses initiation, but promotes tumor progression [17].

\section{Autophagy as a tumor suppressive mechanism}

Autophagy has an anti-inflammatory role [18], removes inflammasomes (responsible for the secretion of inflammatory interleukin- $1 \beta$ and intreleukin-18), damaged mitochondria [19]. It is associated with inhibition of a number of pro-inflammatory signals [20]. Lack of autophagy causes oxidative stress and genomic instability, an inflammatory microenvironment, favorable conditions for malignant transformation and progression. Chronic inflammation, as a result of lack of autophagy due to mutation of Thr300Ala on ATG16L1 gene, is present in Crohn's disease. Patients with Crohn's disease have an increased risk of developing cancer in areas of inflammation because the cells are more susceptible to intracellular bacterial infection, which leads to chronic inflammation, tissue damage and an increased risk of tumorgenesis [21].

Mutation of AMBRA1, Atg5 and Atg7 gene in mice leads to the development of benign neoplasms [22,23].

An increase in oxidative stress activates nuclear factor, erythroid-2-like 2 (NRF2), which can stimulate tumor growth [24]. Loss of autophagy in the liver is toxic, causing chronic hepatocyte death and inflammation processes leading to the development of liver tumors [25]. P62 deficiency reduces toxicity and tumorigenesis caused by lack of autophagy. 
Increased expression of $p 62$ promotes oxidative stress and tumor growth. It is not known how p62 contributes to tumorigenesis, a given protein is involved in several oncogenic signaling pathways through which it can affect, such as NRF2, mTOR and NF-kB [26].

It is involved in maintaining metabolic homeostasis, removing non-functional mitochondria involved in tumor cell metabolism [20].

Autophagy suppresses tumorigenesis by preventing viral and bacterial infections. Cancer-causing pathogens, such as hepatitis B virus, human herpes virus, human papillomavirus types 16 and 18, Epstein-Barr virus, Helicobacter pylori, Streptococcus bovis, Salmonella enterica, and Chlamydia pneumoniae, after infection, activate xenophagy, which removes pathogens and triggers a specific immune response [18].

These facts indicate that autophagy, by preserving homeostasis, helps prevent malignant transformation.

\section{The role of autophagy in tumor promotion}

Autophagy plays a contradictory role in tumors. Although it suppresses tumor promotion and certain aspects of tumorigenesis, autophagy contributes to the survival of established tumors in response to stress. Tumor cells depend on autophagy significantly more than normal cells. Due to increased nutrient consumption and increased proliferation rates, tumor cells suffer from metabolic stress and hypoxia, and increased basal autophagy protects them from apoptosis and necrosis [27]. It also helps in the late stages of tumor progression, dissemination and metastasis. Separation of cells from the extracellular matrix induces autophagy in epithelial cells, which protects them from cell death called anoikis, and allows metastasis [28]. Autophagy helps metastasis and secretion of cytokines, such as the proinvasive cytokine IL6, which is necessary for invasion [29]. Autophagy protein degradation in stellate cells helps the metabolism of tumor cells by secreting amino acids, primarily alanine, whose carbon tumor cells are used for the Krebs cycle. And other carbon sources such as glucose are used to synthesize serine, which in many types of tumor cells is used to produce nucleotides [30]. Inhibition of autophagy blocks cell migration and invasion in vitro and reduces metastasis in vivo, as shown by research on GEMM (genetically engineered mouse model) for hereditary breast cancer [31]. Defects in the autophagy signaling pathway usually limit the proliferation, invasion, and metastasis of malignant cells [20]. In K-ras lung and pancreatic cancers, loss of autophagy directs tumor progression to benign neoplasm, through increased p53 activity. In GEMM lung cancer, the Atg7 deletion redirects the pathological path from carcinoma to benign oncocytomas, or tumors that accumulate damaged mitochondria [22]. Since damaged mitochondria are the main substrate of autophagy, this points to the fact that benign tumors actually have defects in autophagy [32].

\section{The importance of autophagy in the treatment of tumors}

Pharmacological inhibitors such as 3-methyladenine (3-MA), baphilomycin A1 (BafA) and chloroquine (CQ) are used in clinical studies to inhibit autophagy. 3-MA is a class III PI3K inhibitor, Vps34, and inhibits autophagy in the early stages of autophagosome isolation membrane formation. BafA prevents the function of lysosomes, and blocks the late phase of autophagy, the degradation of autophagosomes. CQ as a weak base increases the lysosomal $\mathrm{pH}$ value, also blocking the degradation of the contents. Although these inhibitors are effective, none of them are specific for autophagy, they also participate in other cellular processes such as endocytosis, intracellular transport and lysosome production. Therefore, the use of inhibitors, which aim at 
specific molecules of the autophagy signaling pathway, is suitable for studying the therapeutic effect of inhibiting autophagy.

So far, the use of autophagy inhibitors together with other chemotherapeutics has been shown to be effective in eliminating tumor cells. Imatinib (Gleevaec), a tyrosine kinase inhibitor that inhibits $B C R / A B L$, is conventionally used to treat chronic myeloid leukemia (CML). However, its use leads to CML stem cell resistance and relapse in patients. The combined use of imatinib with CQ significantly leads to the death of tumor cells in as many as three different stages of the disease, in newly diagnosed patients, in patients who use only imatinib and in patients with imatinib resistance. Similar results were achieved with RNA interference of the ATG5 and ATG7 genes, directly linking the inhibition of autophagy with tumor cell death. Studies of the combined use of CQ with chemotherapeutics, performed on other tumor models, have shown that inhibition of autophagy causes p53-mediated apoptosis and tumor regression [33].

Also, recent studies have shown that $\Delta$ 9-tetrahydrocannabinol (THC) causes autophagy in glioma cells, which indirectly causes their death by promoting apoptosis. THC causes endoplasmic reticulum stress and inhibits the AKT/mTOR pathway. Inhibition of autophagy or apoptosis prevents cell death,

Funding source. The authors received no specific funding for this work.

Ethical approval. This article does not contain any studies with human participants performed by any of the authors. which indicates the interdependence of the two processes [34]. Coordination of autophagy and apoptosis has been shown to be necessary for efficient melanoma cell death in in vitro and in vivo studies. Inhibition of autophagy with BafA, CQ, or ATG5 deletion or treatment with caspase inhibitors suppresses cell death suggesting that induction of autophagy is necessary for later activation of apoptosis [35].

\section{Conclusion}

Autophagy is associated with many human diseases, including neurological, autoimmune, infectious diseases, metabolic disorders, and cancer. However, the largest number of clinical trials related to autophagy are, clinical trials of cancer, which involve the inhibition of autophagy. Studies have shown that autophagy plays a key role in suppressing tumor initiation, but also that it helps tumor cell progression and metastasis. Therefore, autophagy both promotes and inhibits tumor growth, and the role of autophagy in cancer therapy depends on the context and should not be generalized. On the other hand, autophagy has a protective role in normal tissues and its deficiency results in neurodegenerative and metabolic disorders, i.e. it is toxic to normal tissues.

Conflicts of interest. The authors declare no conflict of interest. 
References:

1. Massey A, Kiffin R, Cuervo AM. Pathophysiology of chaperone-mediated autophagy. Int J Biochem Cell Biol 2004;36(12):2420-34.

2. Levine B, Klionsky DJ. Development by self-digestion: molecular mechanisms and biological functions of autophagy. Dev Cell 2004;6(4):463-77.

3. Klionsky DJ, Ohsumi Y. Vacuolar import of proteins and organelles from the cytoplasm. Annu Rev Cell Dev Biol 1999;15:1-32.

4. Pubmed - https://pubmed.ncbi.nlm.nih.gov /?term $=\% 28$ Autophagy $\% 29+$ AND $\% 28 \% 28 \%$ $222016 \% 22 \%$ B D a te + - + Public a tion $\% 5 \mathrm{D}+\% 3 \mathrm{~A}+\% 222021 \% 22 \% 5 \mathrm{BDate}+-+$ Publication \%5D \%29\%29 Accessed November 5, 2020

5. Mizushima N. Autophagy: process and function. Genes Dev 2007;21(22):2861-73.

6. Clarke PG. Developmental cell death: morphological diversity and multiple mechanisms. Anat Embryol (Berl) 1990;181(3):195-213.

7. Schweichel JU, Merker HJ. The morphology of various types of cell death in prenatal tissues. Teratology 1973;7(3):253-66.

8. Levine B, Yuan J. Autophagy in cell death: an innocent convict? J Clin Invest 2005;115(10):2679-88.

9. Shen HM, Codogno P. Autophagic cell death: Loch Ness monster or endangered species? Autophagy 2011;7(5):457-65.

10. Pattingre S, Tassa A, Qu X, Garuti R, Liang XH, Mizushima N., et al. Bcl-2 antiapoptotic proteins inhibit Beclin 1-dependent autophagy. Cell 2005;122(6):927-39.

11. Wei Y, Pattingre S, Sinha S, Bassik M, Levine B. JNK1-mediated phosphorylation of Bcl-2 regulates starvation-induced autophagy. Mol Cell 2008;30(6):678-88.

12. Li M, Gao P, Zhang J. Crosstalk between Autophagy and Apoptosis: Potential and Emerging Therapeutic Targets for Cardiac Diseases. Int J Mol Sci 2016;17(3):332.

13. Wu H, Che X, Zheng Q, Wu A, Pan K, Shao A, et al. Caspases: a molecular switch node in the crosstalk between autophagy and apoptosis. Int J Biol Sci 2014;10(9):1072-83.
14. Oral O, Oz-Arslan D, Itah Z, Naghavi A, Deveci $R$, Karacali $S$, et al. Cleavage of Atg3 protein by caspase-8 regulates autophagy during receptor-activated cell death. Apoptosis 2012;17(8):810-20.

15. Han J, Hou W, Goldstein LA, Stolz DB, Watkins SC, Rabinowich H. A Complex between Atg7 and Caspase-9: A novel mechanism of cross-regulation between autophagy and apoptosis. J Biol Chem 2014;289(10):6485-97.

16. Wirawan E, Vande Walle L, Kersse K, Cornelis S, Claerhout S, Vanoverberghe I, et al. Caspase-mediated cleavage of Beclin-1 inactivates Beclin-1-induced autophagy and enhances apoptosis by promoting the release of proapoptotic factors from mitochondria. Cell Death Dis 2010;1:e18.

17. White E. The role for autophagy in cancer. J Clin Invest 2015;125(1):42-6.

18. Deretic V, Saitoh T, Akira S. Autophagy in infection, inflammation and immunity. Nat Rev Immunol 2013;13(10):722-37.

19. Zitvogel L, Kepp O, Galluzzi L, Kroemer G. Inflammasomes in carcinogenesis and anticancer immune responses. Nat Immunol 2012;13(4):343-51.

20. Galluzzi L, Pietrocola F, Bravo-San Pedro JM, Amaravadi RK, Baehrecke EH, Cecconi F, et al. Autophagy in malignant transformation and cancer progression. Embo J 2015;34(7):856-80.

21. Lassen KG, Kuballa P, Conway KL, Patel KK, Becker CE, Peloquin JM, et al. Atg16L1 T300A variant decreases selective autophagy resulting in altered cytokine signaling and decreased antibacterial defense. Proc Natl Acad Sci USA 2014;111(21):7741-6.

22. Cianfanelli V, Fuoco C, Lorente M, Salazar M, Quondamatteo F, Gherardini PF, et al. AMBRA1 links autophagy to cell proliferation and tumorigenesis by promoting c-Myc dephosphorylation and degradation. Nat Cell Biol 2015;17(1):20-30.

23. Takamura A, Komatsu M, Hara T, Sakamoto A, Kishi C, Waguri S, et al. Autophagy-deficient mice develop multiple liver tumors. Genes Dev 2011;25(8):795-800. 
24. Strohecker AM, Guo JY, Karsli-Uzunbas G, Price SM, Chen GJ, Mathew R, et al. Autophagy Sustains Mitochondrial Glutamine Metabolism and Growth of BRAF(V600E)-Driven Lung Tumors. Cancer Discov 2013;3(11):1272-85.

25. Sun B, Karin M. Inflammation and liver tumorigenesis. Front Med 2013;7(2):242-54.

26. Mathew R, Karp CM, Beaudoin B, Vuong N, Chen G, Chen HY, et al. Autophagy suppresses tumorigenesis through elimination of p62. Cell 2009;137(6):1062-75.

27. Degenhardt K, Mathew R, Beaudoin B, Bray $\mathrm{K}$, Anderson D, ChenG, et al. Autophagy promotes tumor cell survival and restricts necrosis, inflammation, and tumorigenesis. Cancer Cell 2006;10(1):51-64.

28. Fung C, Lock R, Gao S, Salas E, Debnath J. Induction of autophagy during extracellular matrix detachment promotes cell survival. Mol Biol Cell 2008;19(3):797-806.

29. Lock R, Kenific CM, Leidal AM, Salas E, Debnath J. Autophagy-dependent production of secreted factors facilitates oncogenic RAS-driven invasion. Cancer Discov 2014;4(4):466-479.
30. Sousa CM, Biancur DE, Wang X, Halbrook CJ, Sherman MH, Zhang L, et al. Pancreatic stellate cells support tumour metabolism through autophagic alanine secretion. Nature 2016;536(7617):479-83.

31. Amaravadi R, Kimmelman AC, White E. Recent insights into the function of autophagy in cancer. Genes Dev 2016;30(17):1913-30.

32. Guo JY, White E. Autophagy, Metabolism, and Cancer. Cold Spring Harb Symp Quant Biol 2016;81:73-8.

33. Chen N, Debnath J. Autophagy and tumorigenesis. FEBS Lett 2010;584(7):1427-35.

34. Salazar M, Carracedo A, Salanueva I. J, Hernandez-Tiedra S, Lorente M, Egia A, Velasco G. Cannabinoid action induces autophagy-mediated cell death through stimulation of ER stress in human glioma cells. J Clin Invest 2009;119(5):1359-72.

35. Tormo D, Checinska A, Alonso-Curbelo D, Perez-Guijarro E, Canon E, Riveiro-Falkenbach E. Targeted activation of innate immunity for therapeutic induction of autophagy and apoptosis in melanoma cells. Cancer Cell 2009;16(2):103-14. 


\section{Funkcija autofagije kao osnovnog procesa očuvanja ćelijske homeostaze}

\section{Nikolina Elez-Burnjaković', Lejla Pojskićz, Sanin Haverić2, Ajla Smajlović2}

'Univerzitet u Istočnom Sarajevu, Medicinski fakultet Foča, Odsjek za pretkliničke predmete, Foča, Republika Srpska, Bosna i Hercegovina

Univerzitet u Sarajevu, Institut za genetski inženjering i biotehnologiju, Sarajevo,

Bosna i Hercegovina

Autofagija je dinamičan proces, očuvan kod svih eukariota. Odgovorna je za razgradnju citoplazmatskog sadržaja. Autofagija je presudna u ćelijskom preživljavanju i ćelijskoj smrti. Ima značajnu ulogu u reakciji ćelije na stres, nedostatku nutrijenata, embrionalnom razvoju, suzbijanju tumora, odgovoru na patogene i starenje. Proces autofagije takođe je uključen u patologiju humanih bolesti, poput tumora, dijabetesa, kardiomiopatije i neurodegenerativnih bolesti poput Alzheimerove i Parkinsonove bolesti. Autofagija je mehanizam koji uključuje degradaciju ćelija, proteina, oštećenih organela i patogena putem lizozomskih mehanizama, pa tako autofagija omogućava preživljavanje ćelije tokom gladi, hipoksije i metaboličkog stresa. Međutim, ako je opsežna i/ili prekomjerna, autofagija može promovisati apoptozu (tip I) ili funkcionisati kao alternativni put ćelijske smrti, koji se naziva autofagna ćelijska smrt (tip II). Autofagija može promovisati smrt ćelija karcinoma ili služiti kao mehanizam preživljavanja protiv apoptoze ili nekroze izazvane raznim tretmanima protiv tumora. $S$ obzirom na kontradiktornu ulogu autofagije tokom inicijacije i progresije tumora, upotreba autofagije u terapiji zavisi od konteksta i mora joj se pristupiti individualno.

Ključne riječi: autofagija, ćelijsko preživljavanje, ćelijska smrt, tumor 